\title{
RELATIONAL MARKETING AND CUSTOMERS SHIFTING TENDENCY IN ISLAMIC BANKING IN EAST JAVA
}

\author{
Purwanto \\ Department of Management - WR Supratman University \\ Arief Rahman Hakim 14, Surabaya 60111 \\ Email: cakpo3r@gmail.com \\ Michael Adiwijaya \\ Petra Christian University \\ Siwalankerto 121-131, Surabaya 60236
}

\begin{abstract}
The purpose of this study was to explain the relationships between relational bonds, customers' value, and customers' loyalty of three consumer groups of Islamic banking in East Java. Samples were obtained from 613 Islamic banks' customers in East Java and were analyzed using SEM. The findings were: For stayers, the three types of bonds raised utilitarian and hedonistic values, which raised loyalty. For dissatisfied switchers, only structural bond affected the utilitarian value, which raised loyalty. For satisfied switchers, social bond affected hedonistic value, while structural bond affected utilitarian value.
\end{abstract}

Keywords: Relationship Marketing, Customers' Loyalty, Utilitarian Value, Hedonistic Value, Islamic Banking

\begin{abstract}
Abstrak
Tujuan dari penelitian ini adalah menjelaskan hubungan antara ikatan relasional, customer value dan loyalitas pada tiga kelompok konsumen pada perbankan syariah di Jawa Timur. Sampel berasal dari 613 nasabah bank syariah di Jawa Timur dan dianalisis menggunakan SEM. Hasilnya: kelompok stayers, tiga tipe ikatan meningkatkan nilai utilitarian dan hedonis, sehingga meningkatkan loyalitas. Kelompok dissatisfied switchers, hanya ikatan struktural yang berdampak terhadap nilai utilitarian, yang meningkatkan loyalitas. Kelompok satisfied switchers, ikatan sosial mempengaruhi nilai hedonik, sedangkan ikatan struktural mempengaruhi nilai utilitarian.
\end{abstract}

Kata Kunci: Pemasaran Relasional, Loyalitas Pelanggan, Nilai Utilitarian, Nilai Hedonis, Perbankan Syariah

\section{INTRODUCTION}

The quick development of Islamic banking industry today demands that people who do business in banking industry should be capable of designing marketing strategies which can attract and maintain their customers, since Islamic banking in East Java which started in 2010 has shown good performance, especially in financing which shows significant growth. At present there are six public Islamic Banks and eight Islamic Enterprise Units with 146 offices which are expected to continue expanding together with the growth of Islamic Banking. This shows that the number of customers of Islamic banks grow significantly from year to year. However, there are also a significant number of customers who switch from one bank to another, either to other Islamic banks or to conventional banks. The dynamic of the switch indicates that the performance of Islamic banks hasn't satisfied the customers' expectations maximally.

People who do business in finance industry should have the skill to understand their customers' behavior in order to satisfy their customers' needs better and to prevent their customers from switching to other companies. Any approach to solve this problem will be welcome, and relational marketing has proved to be one of the most successful approach (Dibb \& Meadows, 2001).

Relational marketing as an attractive marketing activity which maintains and promotes a company's relationship with its customers (Berry, 1983; Berry \& Parasuraman, 1991; Grönroos, 1994) has changed the 
focus of marketing orientation from obtaining short term transactional customers to maintaining a continuing relationship with customers. Many companies carry out relational marketing to encourage customers' loyalty to their products and services (Schiffman \& Kanuk, 2010). The important aspect of relationship marketing is that the relationship forms a 'bond' between a company and its customers (Roberts et al., 2003).

As expressed in many literatures, a company can build a relationship with its customers by creating one or several bonds, including financial bond, social bond, and structural bond (Berry, 1995; Berry \& Pasuraman, 1991; Lin et al. 2003; Peltier \& Westfall, 2000; Williams et al., 1998). However, there are still many things we must learn about the relationship of relational bond initiated by a company to customers' perception and behavior (Gwinner et al., 1998).

Value is another important element in the management of long term relationship with customers (Pride \& Ferrell, 2003). The definition of value varies according to context (Babin et al., 1994; Dodds et al., 1991; Holbrook, 2005; Holbrook \& Corfman, 1985), some conceptualize value as the outcome of consumption experience. In the study of Babin et al. (1994), value was defined as the relative preference of a person after he/she interacted with an object or an event. In developing marketing activity, a company must realize that customers learn from their experience, and well designed marketing can raise customers' perception of value (Pride \& Ferrell, 2003). Thus, customers' experience with relational bond can affect their perception of value.

Present studies of customers' behavior focused on customers' perception of the value of marketing activity. Various literatures evaluated the process of shopping (Babin et al., 1994) and the activity of sales promotion (Ailawadi et al., 2001; Chandon et al., 2000) according to their utilitarian value, or the benefit of economy factor, and hedonistic value or emotional value which resulted from this activity. In this research, the relational bond which was created by economy or emotional marketing activity could raise customers' utilitarian or hedonistic value. If customers truly value these bonds, they are motivated to be loyal.

According to the stimulus-organism-response $(S-O-R)$ paradigm (Woodworth, 1928) and a research on value (Ailawadi et al., 2001; Babin et al., 1994), relational bond activity of a company (stimulus) can affect customers' perception of value (organism), which will eventually affect their buying behavior (response). Thus, relational bond correlates with customers' perception of value, and can raise or lessen customers' loyalty. The principal question which became the basis of this research was how customers responded to relational bond and how this bond promoted long term relationship.

To find out the design and implementation of effective customers' retention strategy, we divided bank customers into three segments: stayers (loyal customers), dissatisfied switchers (customers who switch to another bank because of disappointing experience in the previous bank), and satisfied switchers (customers who switch to another bank because of other reasons than dissatisfaction (Ganesh et al., 2000). In previous literature it was stated that the psychological condition and behavior of clients in one segment differed significantly from the psychological condition and behaviour of clients in another segment (Ganesh et al., 2000; Keaveney \& Parthasarathy, 2001). Therefore, customers from different segments would apply their own utilitarian value in their evaluation of a company's marketing activity. If people were not distinctly shown which value they should apply, the value of their shopping experience could be affected by their own private value, goal, or need (Adaval, 2001; Babin et al., 1994; Mano \& Oliver, 1993).

Specifically, this research aimed to study the effect of various relational bonds on customers' perception of utilitarian and hedonistic values, and on the loyalty of various consumer groups in Islamic Banking industry in East Java. We made a hypothesis that customers' perception of value which mediated the relationship in relational bond, and consisted of marketing activities related to economy and emotion, could raise customers' perception of utilitarian or hedonistic values. If customers put a high value on this relational bond, they were motivated to be loyal.

We analyzed this pattern on three different consumer groups to find out the difference in their attitude and behavior. In subsequent part we discussed previous researches on utilitarian and hedonistic values, strategies for creating relational bond, and customers' loyalty; then we presented the research methodology which included description of the measurement tool we used in analysing the hypotheses. After discussing the research results, we proposed several important implications for managers and further researches.

\section{THEORETICAL BASIS AND HYPOTHESIS}

\section{Utilitarian and Hedonistic Values}

Value is people's evaluation after their experience in interacting with objects or events, and forms 
an important outcome variable in the general pattern of consumption experience (Babin et al., 1994; Holbrook \& Corfman, 1985). Most researchers divide customers' value into two categories, namely utilitarian and hedonistic (for example, Babin et al., 1994; Chandon et al., 2000; Chauduri \& Holbrook, 2001; Hirschman \& Holbrook, 1982; Mano \& Oliver, 1993; Stoel et al., 2004; Chitturi, 2009).

Utilitarian value rises from conscious effort to achieve a desired effect (Babin et al., 1994). This value is instrumental, functional, and cognitive; and represent customers' value as the means to reach the goal (Chandon et al., 2000). For example, economy, ease, and product quality can be classified as utilitarian value (Ailawadi et al., 2001; Chandon et al., 2000; Chaudhuri \& Holbrook, 2001). Marketers are usually certain that customers' choice and preference of a market is directed by utilitarian value (Arnould et al., 2004).

On the other hand, hedonistic value is an outcome which relates to a spontaneous response which is subjective and personal (Babin et al., 1994). Hedonistic value, such as entertainment, exploration, self expression (Ailawadi et al., 2001; Chandon et al., 2000), rises more from pleasure and enjoyment than from duty, and is non-instrumental, experiential, and affective (Chaudhuri \& Holbrook, 2001; Hirschman \& Holbrook, 1982).

\section{The Strategy of Creating Relational Bond}

Several previous studies on relationship marketing focused on three types of strategy in creating financial, social, and structural relational bonds which could improve the relationship between a company and its customers (Berry, 1995; Berry \& Parasuraman, 1991; Lin et al., 2003; Peltier \& Westfall, 2000; Williams et al., 1998).

\section{Financial Bond}

A company can improve the relationship with its customers by creating financial bond, which was defined by Berry (1995) as a type of business practice to increase customers' loyalty through price incentive. Several studies stated that one motivation of customers in making relational exchange was to economize on cash (Berry, 1995; Gwinner et al., 1998; Peltier \& Westfall, 2000; Peterson, 1995). Companies often reward loyal customers with special price offers. For example airlines and big hotels give points to frequent customers as incentives which enable them to obtain extra services from the company (Schiffman \& Kanuk, 2010). Several other researches showed that monetary promotion raised customers' perception of utilitarian value, thus raised the benefit they gained from their purchase (Ailawadi et al., 2001; Chandon et al., 2000). Therefore, financial bond can raise customers' utilitarian value.

\section{Social Bond}

Social bond is personal relationship which focuses on service in order to build a relationship between a company and its customers through interpersonal interaction or friendship (Berry, 1995; Wilson, 1995) and identification (Smith, 1998; Turner, 1970). Promoters of this strategy emphasize on carrying out continuous relationship with customers, studying their needs and maintaining positive relationship with them (Berry, 1995; Williams et al., 1998).

From customers' point of view, the strategy of creating social bond seems to give important psychosocial benefit (Beatty et al., 1996; Gwinner et al., 1998; Reynolds \& Beatty, 1999; Williams et al., 1998). Social bond helps to make customers open their selves, and listen and care, which in turn will improve understanding between customers and the company, and improve customers' openess, too. Social bond positively affects customers' emotion which relates to their experience of the company's service, and play a part in forming affective element in the customers' attitude (Chiu, 2002; Edwards, 1990). Hedonistic value reflects the experiential, emotional, and affective value of consumption (Bellenger et al., 1976; Chandon et al., 2000), therefore a company can strengthen customers' perception of hedonistic value by establishing social bond.

\section{Structural Bond}

The third strategy to raise customers' loyalty is through structural bond, which offers targeted customers the benefit of added value which is difficult or expensive for the company and is not easily obtained from other companies (Berry, 1995). Thus, structural bond is a business practice where a company undertakes to maintain its customers by providing valuable services that are not provided by other resources, for example integrated service through their business associates. Dibb \& Meadows (2001) found that several Islamic banks established structural bond through innovative channels, integrated customers database, and the technology of two ways information exchange. Structural bond can cause customers some cost when they switch to the company's competitors, therefore several researches stated that structural bond 
ranked highest in the hierarchy of relational bonds, and provided the biggest opportunity to achieve continuing competitive advantage (Berry \& Parasuraman 1991; Peltier \& Westfall, 2000).

As defined by Chandon et al. (2000) and Chaudhuri \& Holbrook (2001), utilitarian value was constituted of ease and product quality. Thus, structural bond can strengthen customers' perception of utilitarian value.

\section{The Relationship between Value and Loyalty}

In the study of Oliver (1999), loyalty was defined as "a strong commitment to buy again or to subscribe again a preferred product or service consistently in future time." Several studies stated that customers' value, or the benefit gained played an important role in the determination of customers' long term relationship or loyalty to a company. To maintain the existence and the continuance of long term relationship, customers had to gain benefit from their dealings with the company (Gwinner et al., 1998). Thus, customers' perception of value can be considered as an important determinant of brand and loyalty to the company.

Researches on shopping value also showed direct relationship between shopping value and the value put on shopping activity, therefore the higher the utilitarian and hedonistic values of shopping, the higher also the customers' perception of the value of shopping activity (Babin et al., 1994). By applying several concepts similar to utilitarian value, Cronin \& Taylor (1992) found that ease, price, and availability could affect customers' behavioral intention. Gwinner et al. (1998) and Keaveney (1995) stated that customers were less inclined to switch to other companies if they understood better the economy, time and ease they gained in maintaining relationship with a certain company.

Other studies showed that hedonistic value of shopping, which included commercial friendship or relationship between a company and its customers could raise customers' willingness to maintain relationship. In the study of Gwinner et al. (1998), a respondent in the focus group told about his interaction with a company, "I like this company. This company is really humorous and always has many pleasant jokes. I enjoy doing business with this company." If this positive effect can raise the hedonistic value of shopping, there is greater possibility of the company's product being purchased (Babin \& Attaway, 2000). Therefore we proposed that utilitarian and hedonistic values could predict customers' behavior. This meant that if a customer had a high perception of utilitarian or hedonistic value, he or she would be a loyal customer of the company.

\section{The Relationship between Utilitarian Value and Hedonistic Value}

Relatively lasting attitude has cognitive, affecttive, and connative elements, and affects behavior (Shimp, 2003). Previous researches also showed that the affective element of behavior was post-cognitive (Edwards, 1990), and in connection with customers' behavior, connative element was customers' intention to buy certain products (O'Keefe, 1990; Shimp, 2003). According to Edwards (1990) and McGuire (1969), the cognitive element of behavior included trust, value, and thoughts that related to objects, while the affective element included emotion, feeling, and impulse.

Ray (1973) proposed that customers knew a product or service first, established positive or negative feeling towards the product or service, and then decided to buy or not to buy the product or service. Fishbein \& Ajzen (1975) stated that affective response was based on cognitive element. While utilitarian value is chiefly instrumental, functional, and cognitive (Chandon et al., 2000), hedonistic value relates to a spontaneous response which is more subjective and personal (Babin et al., 1994). Thus, based on the studies of Edwards (1990), Fishbein \& Ajzen (1975) dan Ray (1973), it is logical for us to propose that utilitarian value can predict hedonistic value.

There are six hypotheses in this research which are:

$\boldsymbol{H}_{\boldsymbol{I}}$ : Financial bond positively affects customers' perception of utilitarian value in Islamic banking in East Java.

$\boldsymbol{H}_{2}$ : Social bond positively affects customers' perception of hedonistic value in Islamic banking in East Java.

$\boldsymbol{H}_{3}$ : Structural bond positively affects customers' perception of utilitarian value in Islamic banking in East Java.

$\boldsymbol{H}_{4}$ : Customers' perception of utilitarian value has a positive relationship with customers' loyalty to Islamic banks in East Java.

$\boldsymbol{H}_{5}$ : Customers' perception of hedonistic value has a positive relationship with customers' loyalty to Islamic banks in East Java.

$\boldsymbol{H}_{6}$ : Customers' perception of utilitarian value has a positive relationship with hedonistic value.

\section{RESEARCH METHOD}

We carried out a survey on the customers of Islamic banks in East Java using the convenience sampling method, in which we distributed questionnaires to 613 customers of Islamic banks in East Java. In the questionnaire, the respondent was asked to choose one Islamic bank which served him or her 
during a certain period of time, and then indicated his or her perception of the bank by circling the statements which reflected his or her perception of the bank.

From the 1000 distributed questionnaires, 613 questionnaires were considered valid. The respondents included women (53.7\%) and men (46.3\%) with the age range of 15 to 60 years (mean 30.1 years, median 28 years). The sample measurement of three groups of loyalty was 379 satisfied stayers, 85 dissatisfied switchers, and 149 satisfied switchers.

Based on previous researches, we developed 11 points (Table 1) to measure the relational bond between the respondent and the bank (Beatty et al., 1996; Bendapudi \& Berry, 1997; Berry, 1995; Lin et al., 2003; Williams et al., 1998); to measure utilitarian and hedonistic values we developed five points (Table 2) based on three studies (Babin et al., 1994; Chandon et al., 2000; Spangenberg et al., 1997). For all the points we used the likert scale with five selections (1 extremely disagree and 5 extremely agree).

Table 1. Relational Bond and Variable Indicator

\begin{tabular}{l}
\hline Name of Variable \\
Financial Bond \\
a. Islamic banks offer cumulative points program. \\
b. Islamic banks give presents for regular transactions. \\
c. Islamic banks offer additional discount when customer \\
makes a transaction which exceeds a certain amount \\
Social Bond \\
a. The bank continues to relate with me and establishes a \\
good relationship with me. \\
b. The bank cares about my needs. \\
c. The bank helps me solve problems in my accounts. \\
d. The bank asks my opinion of its services. \\
e. The bank sends me cards or presents on special days. \\
Structiol Bond
\end{tabular}

\section{Structural Bond}

a. The bank provides various ways to obtain information more efficiently.

b. The bank gives me news, research report, or transaction information that I need.

c. The bank provides products or services from other sources to solve my problem.

According to Zeithaml et al. (1996) and Ganesh et al. (2000), when customers praised a company, stated their choice of a company among other companies, or increased their purchase, their behavior showed that they were establishing relationship with the company. Therefore we adopted three indicators, namely "As long as I live here, I won't predict myself to switch to other banks," "I will recommend this Islamic bank to my relatives and friends," "I am willing to continue using the services of this Islamic bank." We measured customers' loyalty construct by using the likert scale with five points.
Table 2. Indicator of Utilitarian Value and Hedonistic Value

\begin{tabular}{l}
\hline Name of Variable \\
\hline Utilitarian Value \\
a. I feel comfortable with this bank. \\
b. I think this bank works efficiently. \\
Hedonistic Values \\
a. Compared to other banks, it is more pleasant to pass the \\
time in this bank. \\
b. I choose this bank not out of necessity, but because I \\
like it. \\
c. I think Islamic banks have good Islamic values.
\end{tabular}

Ganesh et al. (2000) also stated that basically customers of a company could be divided into three groups, namely stayers, dissatisfied switchers, and satisfied switchers. Stayers are customers who don't switch to other companies, dissatisfied switchers are customers who switch to other companies because of dissatisfaction with the previous company, satisfied switchers are customers who switch to other companies because of reasons other than dissatisfaction.

Part of the questionnaire which contained statements designed to measure customers' switching behavior repeated some of the instrument used by Ganesh et al. (2000) in his study. The respondents were asked whether their present banks were their first banks (stayers), or whether they had switched from previous banks (switchers). If the respondents chose the second statement, they were asked to give the reason of the switch, namely whether it was caused by (1) general dissatisfaction of the services of the previous bank (dissatisfied switchers), or (2) reasons other than dissatisfaction (for example, work in another place, move from the territory of the previous bank, the previous bank is liquidated or bought by another bank) (satisfied switchers).

This research aimed to prove and analyze the influence of exogen variable on endogen variable. The influence was quite complex, which included free variable, intermediary variable, and bound variable. The variables were latent variables which were formed by several indicators (observed variables). Therefore in the data analysis of this research we used the Structural Equation Modeling (SEM) technique which employed the AMOS program (Analysis of Moment Structure).

\section{RESEARCH RESULT AND DISCUSSION}

\section{Construct Reliability and Validity}

To test the reliability of the scale for relational bond, customers' value, and customers' loyalty, we used the Alfa Cronbach calculation. Financial bond 
with Alfa value of 0.83 , Social bond with Alfa value of 0.92, Structural bond with Alfa value of 0.85, Utilitarian value with Alfa value of 0.83 , Hedonistic value with Alfa value of 0.88 , and Customers' loyalty with Alfa value of 0.79 . These values showed internal consistency which ranged from moderate to high in the questionnaire points and in the construct related to customers.

To test the construct validity of each scale, we carried out confirmatory construct analysis (CFA) and analyzed covariance matrix by maximum probability procedure at LISREL of 8.50. Fit statistics for relational bond pattern $\left(\chi^{2}=202, d f=41\right.$; goodness-of-fit index $[\mathrm{GFI}]=0.94$; adjusted goodness of fit index, $[\mathrm{AGF}]=0.91$; comparative fit index $[\mathrm{CFI}]=0.97$; root mean residual $[\mathrm{RMR}]=0.07)$ and fit statistics for customer value $\left(\chi^{2}=25, d f=4 ; \quad\right.$ GFI $=0.98$; $\mathrm{AGFI}=0.97 ; \mathrm{CFI}=0.99 ; \mathrm{RMR}=0.01)$ agreed with the ones found in literatures.

Churchill (1979) stated that the convergent validity and discriminant validity of construct should be tested. The average variance extracted (AVE) for financial, social, and structural bonds were subsequently $0.63,0.66$, and 0.70 ; The AVE for utilitarian and hedonistic values were 0.73 and 0.71 . All these values exceeded the suggested value of 0.50 . Therefore, the scale for relational bond and customers' perception of values had convergent validity (Fornell \& Larcker, 1981).

The AVE values could also be used to evaluate discriminant validity (Fornell \& Larcker, 1981), which was clearly seen in the result of this research since the largest shared variance of financial, social, and stuctural bonds factors of 0.55 was lower than the smallest AVE value (0.63) for each factor and its measurement tool in the scale of relational bond (Espinoza, 1999). The shared variance of utilitarian and hedonistic values was 0,53 , which was lower than the smallest AVE value (0.71) for each factor and its measurement tool in the scale of customers' perception of the values.

\section{Test of the Hypotheses}

To find out whether $H_{I}-H_{6}$ are valid for stayers, dissatisfied switchers, and satisfied switchers, we categorized the data into three groups and calculated parameter estimation $(\gamma$ and $\beta$ ) freely in each group with LISREL of 8.50. Then we limited all parameter estimations in a certain group (for example, stayers) in the same way as in another group (for example, satisfied switchers). We tested the difference of $\chi^{2}$ to evaluate the difference in the conformity between unlimited model and limited model. The difference between the two $\chi^{2}$ values ranged from 23 to 137 (df $=6, p=0.05$ ) in the three consumer groups, which indicated that two groups differed significantly in the estimated parameter.

For unlimited stayers model $(n=379)$, the conformity was moderate $\left(\chi^{2}=453.0, d f=143, p<\right.$ 0.05 ; $\mathrm{CFI}=0.94$, GFI $=0.89$, dan RMR $=0.05$ ). Eventhough the model had a strong basis, the potential of the model specification should be taken into consideration (Anderson \& Gerbing, 1988; Brady \& Cronin, 2001) in order to raise the involvement of data in conceptualization, which in turn would raise validity (Bentler \& Chou, 1987).

For stayers, we identified one additional line from structural bond to hedonistic bond. Since stayers had less previous experience of service (Grace \& O'Cass, 2001), their expectations were lower than the expectations of switchers. If the company provided services that were indispensable for customers (structural bond), switchers were more quickly satisfied than stayers. Switchers could take pride in themselves and could be assured that they were clever customers who had selected the best bank for the first time. This stimulated feeling and self confidence belong to hedonistic value (Chandon et al., 2000). Therefore we could add a line between structural bond and hedonistic bond for stayers.

The research result showed that all parameter estimations were significant and supported $H_{I}-H_{6}$. The value of $\chi^{2}$ was $448.8(d f=142)$, which was lower than the initial model $\left(\chi^{2}=453.0, d f=143\right)$, and the values of CFI, GFI, and RMR were subsequently $0.94 ; 0.89$ dan 0.05 . The difference between the two $\chi^{2}$ was 4.2 which was larger than the suggested significant value of $3.84\left(\chi_{0.05,1}{ }^{2}\right)$. Besides, the $\gamma_{23}$ coefficient was 0.36 which was significant at $p<$ 0.05 . The result showed the conformity of models in Figure 1, which raised significantly when compared to the initial model which did not have a line between structural bond and hedonistic value.

For dissatisfied switchers model $(n=85)$, the $\chi^{2}$ was $236.8(d f=143, p<0.05)$, CFI was 0.90 , GFI was 0.80 , and RMR was 0.07 , so the conformity could be accepted. However, there were three insignificant lines. The line from financial bond to utilitarian value $(\gamma=0.34, p>0.05)$ could be insignificant because switchers had more experience with the service of Islamic banks. According to Berry \& Parasuraman (1991) and Peltier \& Westfall (2000), price was the most easily imitated element, so it could not give continuing competitive advantage.

Switchers could obtain the same price incentive from other banks. Therefore financial bond did not 
significantly affect their utilitarian value. The second insignificant line was between social bond and hedonistic value $(\gamma=0.01, p>0.05)$ which could occur because dissatisfied switchers switched from other companies because of their dissatisfaction. This negative experience could cause them to distrust or to be cautious in accepting interpersonal attention from a company; thus social bond could not strengthen their hedonistic value. Lastly, the line between hedonistic value and customers' loyalty was not significant either $(\gamma=0.26, p>0.05)$, which indicated that hedonistic and affective responses did not present serious problems for dissatisfied switchers. However, utilitarian value could be a key towards their loyalty.

For unlimited satisfied switchers model $(n=$ 149), $\chi^{2}$ was $281,6(d f=143, p<0.05)$, and CFI, GFI, and RMR were subsequently $0.92 ; 0.83$ and 0.07 , which indicated that the conformity could be accepted. The only significant line was from financial bond to utilitarian value $(\gamma=-0.22, p>0.05)$. The reason of this finding might be the same as the parallel explanation for dissatisfied switchers. Because switchers had more experience with bank services, they might find similar price incentive from other banks.

\section{Discussions}

In this research, we applied the concept of relationship marketing in retailed banking service in an empirical study. According to S-O-R paradigm, the relational bond offered by a bank (stimulus) could affect customers' utilitarian and hedonistic values (stimulus), which affected customers' loyalty (response) to the bank. The result showed that financial and structural bonds positively affected customers' utilitarian value, while social bond positively affected customers' hedonistic value. Both utilitarian and hedonistic values positively affected customers' loyalty.

According to the findings of Ganesh et al. (2000), customers who switched to other companies because of their dissatisfaction of the previous company differed significantly from other group of customers in satisfaction and loyalty behavior. As switchers they could obtain similar services and had more experience concerning the industry (Grace \& O'Cass, 2001), which changed their expectations when compared to stayers. While Parasuraman et al. (1985) stated that service quality expressed the difference between customers' perception and customers' expectations. Therefore, different level of expectations could cause different level of evaluations, which explained the difference of behaviors among stayers, dissatisfied switchers, and satisfied switchers.
To find out whether $H_{I}-H_{6}$ are valid for stayers, satisfied switchers, and dissatisfied switchers, we studied the relationship between relational bond, customers' value and customers' loyalty in the three consumer groups. All the hypotheses are valid for stayers. Besides, a modified model which added one line from structural bond to hedonistic value was significantly better than the initial model. Structural bond strengthened not only the utilitarian value but also the hedonistic value of switchers.

On the other hand, it was structural bond that significantly affected the utilitarian value of dissatisfied switchers, and only utilitarian value that significantly affected their loyalty. Thus, for dissatisfied switchers, structural bond was the most effective means to increase customers' loyalty. Lastly, for satisfied switchers, structural bond significantly affected utilitarian value, social bond significantly affected hedonistic value, and both utilitarian and hedonistic bonds significantly affected customers' loyalty. Thus for satisfied switchers, social and structural bonds effectively raised customers' loyalty.

The results of this research proved that stayers obtained values from the three relational bonds, and dissatisfied switchers perceived only the value from structural bond. Previous literatures provided information about why stayers had the highest perception of values. Because they did not have many experiences with other banks, were not used to offers of services from other banks, and could perceive higher switching cost when compared to the other two groups of customers, stayers remained loyal to a company eventhough they might have some dissatisfactions (Ganesh et al., 2000; Oliver et al., 1992).

Besides, cognitive dissonance theory states that people usually try to reduce the inconsistency of their attitude, or the inconsistency between their attitude and their behavior (Festinger, 1957). Thus, stayers tend to make up their minds that the company they choose offers higher values than its competitors, in order to lessen their dissatisfaction of the company.

On the other hand, relationship marketing activity cannot affect the perception of dissatisfied switchers, except through relational bond. Concerning their involvement in purchasing, or the attention needed for a purchase and the effort they must exert in making a purchase (Baumgartner, 2002), previous literatures affirmed that dissatisfied switchers showed higher involvement in purchase than the other two consumer groups (Ganesh et al., 2000). Customers who had high involvement in purchase tended to apply higher standard in their evaluation of products and services, so if a company's marketing activity was not better than other companies, the customers would not perceive the value of this activity. 


\section{CONCLUSIONS AND SUGGESTIONS}

The research concluded that for stayers all the hypotheses are valid, or show significant relationship between relationship bonds and utilitarian and hedonistic values; For dissatisfied switchers, the third hypothesis is not valid, namely structural bond does not significantly affect utilitarian value; For satisfied switchers, the only valid hypothesis is the first one, namely financial bond positively affects utilitarian value, while the other five hypotheses are not valid.

And it suggested that Islamic banks should understand how the strategies of creating relational bonds work. Eventhough there are many ways for banks to carry out relationship with customers, there are three specific bonds which have proved to be quite successful, namely financial bond, social bond, and structural bond; Islamic banking should be able to differentiate the relational bond between stayers and switchers. Financial bond significantly affects utilitarian value of stayers, social bond affects hedonistic value of stayers and satisfied switchers, and structural bond raises the utilitarian value of the three consumer groups, and significantly affects the hedonistic value of stayers; Islamic banks should focus on one or several of these relational bonds and use them to differentiate their company from their competitors in front of each consumer group.

However, this research had two principal weaknesses. The first was external validity, namely the ability to generalize the results outside of Islamic banks. Secondly, we only included banking industry and the margin of error lay in generalizing conclusions of this research for other types of industries.

\section{REFERENCES}

Adaval, R. 2001. Sometimes It Just Feels Right: The Differential Weighting of Affect-consistent and Affect-inconsistent Product Information. Journal Consumer Research, 28(1): 1-17.

Ailawadi, K. L., Neslin, S. A., \& Gedenk, K. 2001. Pursuing the Value-conscious Consumer: Store Brands Versus National Brand Promotions. Jounal of Marketing, 65(1): 71-89.

Anderson, J. \& Gerbing, D. 1988. Structural Equation Modeling in Practice: A Review and Recommended Two Step Approach. Psychologycal Bulletin, 103(3): 411-423

Arnould, E. J., Price, L. L., \& Zinkhan, G. M. 2004. Consumers. New York: McGraw-Hill.

Babin, B. J. \& Attaway, J. S. 2000. Atmospheric Affect as a Tool for Creating Value and Gaining Share of Customer. Journal of Business Research, 49(2): 91-99.
Babin, B. J., Darden, W. R., \& Griffin, M. 1994. Work and/or Fun: Measuring Hedonic and Utilitarian Shopping Value. Journal Consumer Research, 20(4): 644-656.

Baumgartner, H. 2002. Toward a Personology of the Consumer. Journal Consumer Research, 29(2): 286-292.

Beatty, S. E, Mayer, M. L., Coleman, J. E., Reynolds, K. E., \& Lee, J. 1996. Customer-sales Associate Retail Relationships. Journal Retail, 72(3): 223247.

Bellenger, D. N., Steinberg, E., \& Stanton, W. W. 1976. The Congruence of Store Image and Self Image. Journal Retail, 52(1): 17-32.

Bendapudi, N. \& Berry, L. L. 1997. Customers' Motivations for Maintaining Relationships with Service Providers. Journal Retail, 73(1): 15-37.

Bentler, P. M. \& Chou, C. P. 1987. Practical Issues in Structural Modeling. Sociological Methods Research, 16(1): 78-117.

Berry, L. L. 1983. Emerging Perspectives on Service Marketing. Chicago: American Marketing Association.

1995 Relationship Marketing of Services: Growing Interest, Emerging Perspectives. Journal of the Academy of Marketing Science, 23(4): 236-245.

Berry, L. L. \& Parasuraman, A. 1991. Marketing Service-Competing Through Quality. New York: The Free Press.

Brady, M. K. \& Cronin, J. J. 2001. Some New Thoughts on Conceptualizing Perceived Service Quality: a Hierarchical Approach. Journal of Marketing, 65(3): 34-49.

Chandon, P., Wansink, B., \& Laurent, G. 2000. A Benefit Congruency Framework of Sales Promotion Effectiveness. Journal of Marketing, 64 (4): 65-81.

Chaudhuri, A. \& Holbrook, M. B. 2001 The Chain of Effects from Brand Trust and Brand Affect to Brand Performance: The Role of Brand Loyalty. Journal of Marketing, 65(2): 81-93.

Chitturi, R. 2009. Emotions by Design: A Consumer Perspective. International Journal of Design, 3 (2): 7-17.

Chiu, H. C. 2002. A Study on the Cognitive and Affective Components of Service Quality. Total Qualily Management, 13(2): 265-274.

Churchill, Jr. G. A. 1979. A Paradigm for Developing Better Measures of Marketing Constructs. Journal of Marketing Research, 16(1): 64-73.

Colgate, M. \& Hedge, R. 2001. An Investigation into the Switching Process in Retail Banking Services. International Journal of Bank Marketing, 19(5): 201-212. 
Cronin, Jr. J. J. \& Taylor, S. A. 1992. Measuring Service Quality: A Reexamination and Extension. Journal of Marketing, 56(3): 55-68.

Dibb, S. \& Meadows, M. 2001 The Application of a Relationship Marketing Perspective in Retail Banking. The Service Industries Journal, 21(1): 169-194.

Dodds, W. B., Monroe, K. B., \& Grewal, D. 1991. Effect of Price, Brand, and Store Information of Buyers' Product Evaluations. Journal of Marketing Research, 28(3): 307-319.

Edwards, K. 1990. The Interplay of Affect and Cognition in Attitude Formation and Change. Journal of Personality and Social Psychology, 59(2): 202-216.

Espinoza, M. M. 1999. Assessing the Cross-cultural Applicability of a Service Quality Measure: A Comparative Study Between Quebec and Peru. International Journal of Service Industries Management, 10(5): 449-468.

Festinger, L. 1957. A Theory of Cognitive Dissonance. Stanford: Stanford University Press.

Fishbein, M \& Ajzen, I. 1975. Belief, Attitude, Intention and Behavior: An Introduction to Theory and Research. Reading: Addison-Wesley.

Fornell, C \& Larcker, D. F. 1981. Evaluating Structural Equation Models with Unobservable Variables and Measurement Error. Journal of Marketing Research, 18(1): 39-50.

Ganesh, J. M., Arnold, J., \& Reynolds, K. E. 2000. Understanding the Customer Base of Service Providers: An Examination of the Differences Between Switchers and Stayers. Journal of Marketing, 64(3): 65-87.

Grace, D. \& O'Cass, A. 2001. Attributions of Service Switching: A Study of Consumers' and Providers' Perceptions of Child-care Service Delivery. Journal of Service Marketing, 15(4): 300321.

Grofnroos, C. 1994. From Marketing Mix to Relationship: Towards a Paradigm Shift in Marketing. Management Decision, 32(2): 4-21.

Gwinner, K. P., Gremler, D. D., \& Bitner, M. J. 1998. Relational Benefits in Service Industries: The Customer's Perspective. Journal of the Academy of Marketing Science, 26(2): 101-114.

Hirschman, E. C. \& Holbrook, M. B. 1982. Hedonic Consumption: Emerging Concepts, Methods and Propositions. Journal of Marketing, 46(3): 92-101.

Holbrook, M. B. 2005. Customer Value and Autoethnography: Subjective Personal Introspection and the Meanings of a Photograph Collection. Journal of Business Research, 58(1): 45-61.
Holbrook, M. B. \& Corfman, K. P. 1985. Quality and Value in the Consumption Experience: Phaedrus Rides Again. Lexington: Lexington Books.

Keaveney, S. M. 1995. Customer Switching Behavior in Service Industries: An Exploratory Study. Journal of Marketing, 59(2): 71-82.

Keaveney, S. M. \& Parthasarathy, M. 2001. Customer Switching Behavior in Online Services: An Exploratory Study of the Role of Selected Attitudinal, Behavioral, and Demographic Factors. Journal of the Academy of Marketing Science, 29(4): 374-390.

Lin, N. P., Weng, J. C. M., \& Hsieh, Y. C. 2003. Relational Bonds and Customer's Trust and Commitment - A Study on the Moderating Effects of Web Site Usage. The Service Industries Journal, 23(3): 103-124.

Mano, H. \& Oliver, R. 1993. Assessing the Dimensionality and Structure of the Consumption Experience: Evaluation, Feeling and Satisfaction. Journal of Consumer Research, 20(3): 451 - 466.

McGuire, W. J. 1969. The Nature of Attitudes and Attitude Change. Reading: Addison-Wesley Publishing.

O'Keefe, D. J. 1990. Persuasion: Theory and Research. Newbury Park: Sage Publications.

Oliva, T. R., Oliver, L., \& MacMillan, I. 1992. A Catastrophe Model for Developing Service Satisfaction Strategies. Journal of Marketing, 56 (3): 83-95.

Oliver, R. L. 1999. Whence Consumer Loyalty?. Journal of Marketing, 63(Special issue): 33-44.

Parasuraman, A., Zeithaml, V. A., \& Berry, L. L. 1985. A Conceptual Model of Service Quality and Its Implications for Future Research. Journal of Marketing, 49(3): 41-50.

Peltier, J. W. \& Westfall, J. 2000. Dissecting the HMO-benefits Managers Relationship: What to Measure and Why. Journal of Marketing Health Service, 20(2): 4-13.

Peterson, R. A. 1995. Relationship Marketing and the Consumer. Journal of the Academy of Marketing Science, 23(4): 278-281.

Pride, W. M. \& Ferrell, O. C. 2003. Marketing: Concepts and Strategies. Boston: Houghton Mifflin Company.

Ray, M. L. 1973. Communication and the Hierarchy of Effects. Beverly Hills: Sage Publications.

Reynolds, K. \& Beatty, S. 1999 A Relationship Customer Typology. Journal of Retail, 75(4): 509-523.

Roberts, K., Varki, S., \& Brodie, R. 2003. Measuring the Quality of Relationships in Consumer Services: An Empirical Study. European Journal of Marketing, 37(1/2): 169-196. 
Schiffman, L. G. \& Kanuk, L. L. 2010 Consumer Behavior. Upper Saddle River: Pearson Prentice-Hall.

Shimp, T. A. 2003. Advertising, Promotion, and Supplemental Aspects of Integrated Marketing Communications. Mason: South-Western Publishing.

Smith, B. 1998. Buyer-seller Relationships: Bonds, Relationship Management, and Sex-type. Canadian Journal of Administrative Science, 15(1): 76-92.

Spangenberg, E. R., Voss, K. E., \& Crowley, A. E. 1997. Measuring the Hedonic and Utilitarian Dimensions of Attitude: A Generally Applicable Scale. Advances in Consumer Research, 24(7): 235-241.

Stoel, L., Wickliffe, V., \& Lee, K. H. 2004. Attribute Beliefs and Spending as Antecedents to Shop- ping Value. Journal of Business Research, 57(10): 1067-1073.

Turner, R. H. 1970. Family Interaction. New York: John Wiley.

Williams, J. D., Han, S. L., \& Qualls, W. J. 1998. A Conceptual Model and Study of Cross-cultural Business Relationships. Journal of Business Research, 42(2): 135-143.

Wilson, D. T. 1995. An Integrated Model of Buyerseller Relationships. Journal of the Academy of Marketing Science, 23(4): 335-345.

Woodworth, R. S. 1928. Dynamic Psychology. Worcester: Clark University Press.

Zeithaml, V. A., Berry, L. L., \& Parasuraman, A. 1996. The Behavioral Consequences of Service Quality. Journal of Marketing, 60(2):31-46. 